\title{
THE ROLE OF POLISH COURTS IN THE DEVELOPMENT OF INTERNATIONAL LAW AFTER REGAINING INDEPENDENCE BY POLAND IN 1918
}

\begin{abstract}
The article explores the question to what extent Polish courts could have contributed to the development of international law between the two World Wars, after Poland regained independence in 1918 and began rebuilding the State. This is also a period when the practice of national courts was particularly important for the elaboration of general standards of conduct in numerous areas of international law. Many of the decisions of Polish courts, especially those that concern the consequences of succession of States, the occupation of enemy territory, nationality and statelessness, diplomatic and State immunities or effects of the treaties were relevant in this process.
\end{abstract}

Keywords: Poland; independence; contribution of Polish courts; practice of national courts; consequences of succession of States; occupation of enemy territory, nationality and statelessness

* Professor, Chair of the European Constitutional Law Department, University of Łódź, ORCID: 0000-0002-3310-6675. 


\section{Introduction}

Claims based on international law naturally appear before domestic courts. This was especially evident when there were no international courts at all. The first international courts were set up as ad hoc institutions, and international courts were established at the end of the $19^{\text {th }}$ century. The Permanent Court of Arbitration was created in 1899, and the Permanent Court of International Justice in 1920. Until then many issues of international law were considered and resolved by domestic judges. To play any role in the international sphere, the decisions of domestic judges must be known to other international players. Owing inter alia to A. McNair and H. Lauterpacht, who were the 'chief inspirers' of the Annual Digest of Public International Law Cases (the ancestor of the International Law Reports), the decisions of national courts began to be collected and made accessible internationally. ${ }^{1}$ The first volume containing the judgments adopted between 1925-1926 appeared in 1929. The quantity and the quality of these judicial decisions had exceeded the expectations of the rapporteurs. It is not surprising that afterwards not only McNair's 'The Law of Treaties' or Oppenheim`s textbook on international law referred to these case law in many aspects of international law.

At the end of the $19^{\text {th }}$ century, Poland did not exist as a State and had been partitioned for almost one hundred fifty years between Germany, Russia and Austria-Hungary. The country regained independence in 1918 and immediately began to rebuild State organs, including the judiciary. The questions of international law had come quite quickly before Polish judges. They had to decide on the issues of Polish nationality, statehood, its continuation, recognition and succession, diplomatic law, immunities, effects of treaties in domestic law, etc. It is amazing how many of these cases were reported in the Annual Digest of Public International Law Cases. Thanks to the fact that they were published in English, they could be studied, analysed and commented on, as for example cases concerning

1 This was the first collection of national court decisions concerning international law. The Annual Digest was first published under the direction of the Department of International Studies of the London School of Economics. For details, see R.Y. Jennings, The Judiciary, International and National, and the Development of International Law, 'ICLQ', vol. 45 , no. 1 , p. 1 et seq. 
various aspects of succession of States by D.P. O'Connell in his remarkable work on 'The Law of State Succession'.

The purpose of this article seems self-pronouncing. We will make an inquiry into the extent of the contribution of Polish courts to the development of international law in the period between the two World Wars, after the regaining of independence by Poland and building a new internal legal system. This is also an early period of the crystallisation of the rules of modern international law, when the practice of national courts as a part of State practice was particularly important for the elaboration of general standards of conduct.

\section{Legal consequences of succession of States}

According to the definition adopted by leading contemporary legal documents on the consequences of the succession of States, the succession of States means 'the replacement of one State by another in the responsibility for the international relations of territory.' ${ }^{3}$ Poland replaced three States: Russia, Germany and Austria-Hungary, in relation to the territories ceded to Poland after 1918. All important issues of State succession in relation to e.g. State property, debts, nationality or treaties arose before domestic courts at that time. Domestic courts deal primarily with the rights of individuals. The individuals brought a huge variety of private law claims before the Polish courts, giving them the opportunity to express themselves on the general position of Poland in respect to its statehood, continuity, recognition and succession. The Polish courts have consistently held that Poland is neither a successor of Germany, Austria-Hungary or Russia due to the cession of territory, nor is it a new State, but it continues its statehood as before the partitions. However, as in the case of cession of territory or secession, if it did not accept special treaty obligations, Poland did not enter into any obligations, either international, public or private, of the partitioning Powers. The laws introduced by the partitioning Powers or

2 D.P. O'Connell, The Law of State Succession, Cambridge 1956.

3 Cf. Article 2(1)(b) of the Vienna Convention on Succession of States in Respect of Treaties of 1978; Article 1(1)(a) Vienna Convention on Succession of States in Respect of State Property, Archives and Debts of 1983; Article 2(a) United Nations International Law Commission 'Draft Articles on Nationality of Natural Persons in Relation to the Succession of States' of 1999. 
effects of their administrative acts or private law acts remain only in so far as they are not in contradiction with the independence of Poland.

One of the early judgments regarding these issues was the decision of 1922 in the Pantol case. The Supreme Court distinguished between the creation of the State, its recognition by third States and its primary creation and its rebirth. The Court held that the recognition of the State has only a declaratory character and that:

the restitution of the State or rather renewal of the State activity, which has existed before for long centuries, but has lost temporarily the ability to act is basically the process of restoration of the regular organs of the State, to which it is enough the constant tradition and the will of the enlighten part of the nation, striving undeterred for regaining the statehood and kind, even if mercenary, external aid. The tradition of Polish statehood exists at least since ten hundreds of years, and the indications of the constant will of the nation to keep its own statehood were the victims of martyrdom of hundreds of thousands of Poles, dying for their homeland and constant revolutionary movements aimed at abolition of the laws and organization imposed by the three Powers. ${ }^{4}$

\section{After a thorough analysis of the history of Poland, the Court concluded that:}

The States collapse only if people lose the sense of social distinctiveness in view of foreign invasion, when the social awareness of inhabitants is changing, when however slowly but decisively the consent for new order will ensue, when the tradition completely disappear and the constant will to keep alive old aspirations, beliefs and forms of life in a group (...) . ${ }^{5}$

In the Court's opinion, this process did not happen in the case of Poland. The State had existed even in the time of partition on the same territory, except for some accepted changes of the borders in 1919.

4 Judgment of the Supreme Court, Pantol case, O.S.P., II., no. 346; cited by L. Ehrlich, Prawo Narodów [Law of Nations], $3^{\text {rd }}$ ed., Kraków 1947, pp. 134-135; mentioned in the commentary to Kulakowski and others v. Szumkowski, Annual Digest 1927-1928, p. 553. The case concerned the responsibility for treason. The Court had to answer whether, at the time the crime was committed, the relevant territory belonged to Poland.

5 Ibidem. 
Consequently, the laws of the three Powers had been repealed, and many of their acts were found not valid. ${ }^{6}$

Regarding the issue of private law obligations, the Supreme Court explained in State Treasury v. Von Bismarck that:

No generally recognized international custom prescribes that a State which is successor to another State accepts solely by reason of State succession the obligations at private law of the State which was its predecessor. $^{?}$

There exists, according to the judgment, a special reason why Poland may rely on this absence of customary law. Poland was a State re-established after a period of partitions. The partitions were never recognised by the Polish nation or government. Even if they lasted for a long time, they were condemned by various forms of protest, including insurrections. Furthermore, the partitions of Poland were an act of violence, as with enemy occupation. The reconstruction of Poland and recognition of her sovereignty in Article 87 of the Treaty of Versailles of 1919 constituted only a restitution, after the removal of German occupation, of the state of affairs that existed before. It is not even a case of succession through the cession of the territory nor the creation of a new State. Consequently, Poland had only such obligations with regard to these territories as it undertook voluntarily in the Treaty. ${ }^{8}$

6 See also e.g. Poland v. Harajewicz, Judgment of the Supreme Court of 16.01.1923, Annual Digest 1923-1924, Case no. 1, p. 9 et seq.; O.S.N., 1923, no. 13; Attorney-General of Poland v. Serewicz, Judgment of the Supreme Court of 1.02.1923, Annual Digest 1923-1924, Case no. 25, pp. 54-55; O.S.P., II, no. 609; Attorney-General of Poland v. Tomecki, O.S.N. 1923, no. 86; Judgment of the Supreme Court of 1.02.1923; Attorney-General of Poland v. Zalewski, Judgment of the Supreme Court of 1.06.1922, O.S.N. 1923, no. 88, O.S.P. II, no. 671.

7 State Treasury v. Von Bismarck, Judgment of the Supreme Court of 28.04.1923, O.S.P., II, no. 498; Annual Digest 1923-1924, Case no. 39, pp. 80-81.

8 In State Treasury v. Von Bismarck (op.cit.), the Court underlined that Poland does not even have a moral obligation to fulfil certain obligations of the Prussian State. The case concerned special properties introduced, as the Supreme Court observed, by Prussia for Germanisation purposes ('properties held on fee-farm rents' [Rentengüter]) directed against the Polish nation and the idea of the Polish State. According to the Court, the Polish State could not be required to continue the policies of the Prussian State in violation of its own interests. The decisions of Polish courts concerning Rentengüter were criticised, see f. 26. 
This view was developed in 1928 in Szumski v. Kułakowski and others. ${ }^{9}$ The Supreme Court found invalid the confiscation by the Russian authorities of the property of the applicant's father as a punishment for his participation in the national uprising of 1863 and its later sale to the defendant. The Court emphasised that the fight against the invader was not a crime but the right and duty of all Poles. If the occupant has appropriated and sold public or private property that may not legitimately be appropriated by a military occupant, the original owner may reclaim that property without payment of compensation. According to the Court the acts of the occupant must be considered not as legal action but rather the acts of violence. ${ }^{10}$ In a similar case in Uszycka v. State Treasury the Court repeated its reasoning and declared that the property in question had never ceased to form the property of the person from whom it had been taken by the Russian authorities. ${ }^{11}$

One may find in these cases traces of the ius post limini doctrine: things taken by the enemy were restored to their former status upon coming again under the power of the nation to which they formerly belonged. Post liminium applies to territory, to private immovable property and to every kind of property that may not lawfully be seized. But property, public or private, that has been lawfully taken by an enemy is not subject to this fiction.

The succession of Poland to the rights and obligations of the predecessors was partly regulated by such treaties as the Treaty of Versailles or the Peace Treaty of St. Germain. On their basis, the courts found that Poland acquired some private or public law rights of the partitioning Powers. In State Treasury v. city of Gniezno, ${ }^{12}$ the Supreme Court found that the Polish State Treasury may enforce the rights which belonged formerly to the Prussian State. It may request unpaid instalments which were due upon the agreement of 1866 concluded between the city of Gniezno and

9 Szumski v. Kułakowski and others, Judgment of the Supreme Court, Z.O.S.N. I C 1928, p. 156-157, broadly cited by L. Ehrlich, op.cit., p. 135-136. The case is also reported in the Annual Digest 1927-1928 (p. 551-553, Case No. 375) but under the title Kulakowski and Others (appelants) v. Szumkowski (respondent) - the judgment of 12.05.1928, Z.O.S.N.C., 1928, no. 98; O.S.P., VIII, no. I.

10 See the commentary to Case no. 375 in Annual Digest 1927-1928, p. 553.

11 Uszycka v. State Treasury, Judgment of the Supreme Court of 4.03.1930, O.S.N.C.T.,1930, no. 43 G.S.W. 1930, p. 573, Annual Digest, 1929-1930, Case no. 289, 492.

12 State Treasury v. city of Gniezno, Judgment of the Supreme Court of 6.06.1930, O.S.N.C., III, 1930, no. 52, Annual Digest 1929-1930, Case no. 31, p. 54. 
the Prussian State. The city of Gniezno was obliged under this agreement to pay quarterly contributions towards the secondary school situated on its territory. The Supreme Court based the right on Article 256 of the Treaty of Versailles, stipulating that Poland had acquired all the property and possessions of the German States situated in its territory. This should also mean, in the opinion of the Court, the rights which the Prussian State derived from the agreement of 1866, even if this were the right to demand payments to be made to a third party. The Court further explained that there was no inconsistency between this decision and the view adopted previously by the Supreme Court that the Polish State was not the successor of the German States (Prussia and Germany). The Polish State had acquired the property and possessions of Prussia and Germany not by succession but modo originario, i.e. without any liabilities. ${ }^{13}$

The same view was expressed by the Supreme Court in regard to the rights belonging formerly to Austria, which passed to Poland on the basis of Article 208 of the Peace Treaty of St. Germain of 10.09.1919. Article 208 used the same term as Article 256 of the Treaty of Versailles - 'all property and possessions'. The Court found that the term also included pecuniary claims. ${ }^{14}$ The Supreme Court acted on an appeal against the decisions of the lower courts in an action brought by the Polish State Treasury against Mrs Czosnowska to recover debt due to the credit she had obtain in 1916, during World War I, from the Austrian government to restore her farm, which had been destroyed during the war.

In Niedzielscy v. State Treasury, ${ }^{15}$ the Supreme Court dealt with the debts of the predecessor and held that Poland is not responsible for the unpaid contract for glassworks performed in the public building of the former Austrian Empire, now situated on Polish territory. The Court

13 Ibidem

14 State Treasury v. Czosnowska, Judgment of the Supreme Court of 11.06.1929, O.S.N.C., III, 1929, no. 207, Annual Digest 1929-1930, Case no. 32, p. 55.

15 Niedzielscy v. Polish Treasury, Judgment of the Supreme Court of 13.10.1925, O.S.P. VI, no. 271; Rw. III, 1485/26/I., Annual Digest 1925-1926, no. 53, pp. 74-75. L. Ehrlich, op. cit., p. 468. The Supreme Court explained that the territories in question were ceded not to Poland, but to Allied and Associated Powers (Article 91 of the Treaty of St. Germain), which in turn handed them over to Poland. It is true that Poland took over all the immovable property belonging to the Austrian State, but apart from school buildings, hospitals and State forests, Poland had to pay for the properties taken over by a contribution to the cost of war to be paid to the Allied Powers. There is thus no question of unjustified enrichment. 
observed that in contradistinction to the older doctrine of international law, the modern law of nations no longer recognises the private law principles of succession as applicable to the transfer of territory from one State to another. The successor State takes over the debts of its predecessor only in so far as it has expressly accepted them. ${ }^{16}$

Regarding the administrative acts of the predecessor, the Supreme Administrative Court, in a case concerning the return of the State building promised by the Austrian government, ruled that:

(...) in relation to all administrative acts of the former partitioning State, the newly created State must be free and has the right, unless international treaties concluded with the former State do not stipulate otherwise, not to recognize these acts (...). ${ }^{17}$

The next judgment - Gil v. Polish Ministry of Industry and Commerce refers to succession in respect to international treaties. The plaintiff, a Russian subject, applied to the Polish authorities for the necessary document to enable him to carry on trading in textile goods in Lviv, a part of Poland formerly belonging to Austria-Hungary. In order to prove the fulfilment of the condition of reciprocity required under Polish law, he referred to the Treaty of Commerce concluded between Russia and Austria-Hungary, claiming that it is still binding on Poland. The Supreme Administrative Court answered that international treaties, being based on the mutual consent of the contracting parties, are not binding on a State for the sole reason that part of its territory formerly belonged to one of the contracting parties. There is a lack of identity of parties to the Treaty. The Austro-Russian Treaty of Commerce of 1906 was binding neither on Poland with regard to Russia nor on Russia with regard to Poland. ${ }^{18}$

16 On succession in contractual obligations, see also Polish State Treasury v. Borak and Another, Judgment of the Supreme Court of 13.05.1925, O.S.P. IV, no. 268; Annual Digest 1925-1926, Case no. 51. The Supreme Court found that Poland is not bound by the contract concluded with the Austrian government authorising defendants to exploit the State forests. The forests then become Polish public property, and Polish authorities requested the defendants to remove certain buildings which they had erected under Austrian government permission on State property.

17 Judgment of the Supreme Administrative Court, Z.W.N.T.A., I, 1923, no. 243. Cited by Ehrlich, op. cit., p. 467.

18 Gil v. Polish Ministry of Industry and Commerce, Judgment of the Supreme Administrative Court of 6.06.1923, O.S.P., II, no. 665; Annual Digest, Case no. 41, pp. 83-84; Reported also by L. Ehrlich, op.cit., pp. 466-467. 
Ludwig v. Ministry of Finance illustrates the question of succession of pension liabilities of the predecessors. The Supreme Administrative Court dismissed the case of an official of the Austrian Finance Administration who was pensioned off. He questioned the amount of pension he received later under the Polish Law of 1921. He contended that pensions of the former Austrian State officials were 'debts of the former Austrian State of which the present Government is heir and which it has the duty of paying and this according to the value of the gold crown in relation to the Polish mark'. The Supreme Administrative Court noted that Poland was not obliged to take over the pension liabilities of predecessors, it is not the successor State in regard of the partitioning Powers and that the Polish State had only voluntarily accepted the pension liabilities within the limits determined in the Law of $1921{ }^{19}$

Similarly, in the case concerning service flats (flats granted to civil servants), which the Polish government abolished and requested to deduct from the official salary the value of the flat and the costs of heating and electricity, not formerly taken according to the Austrian regulations, the Supreme Administrative Court ruled:

By itself, it is understood that the new State is in power in place of the legal system found in the ceded territories, to introduce a new legal order, different from the previous one. ${ }^{20}$

Few cases decided by Polish courts dealt with the issues of State succession to international responsibility for injuries to aliens, for instance Dzierzbicki, ${ }^{21}$ Niemiec and Niemiec v. Bialobrodziec and the State Treasury and Olpinski v. the Treasury (Railway Division). These cases supported the general principle that the continuing State should remain responsible for its own

19 Ludwig v. Polish Ministry of Finance, Judgment of the Supreme Administrative Court of 12.02.1924, Z.W.N.T.A., II, no. 298; Annual Digest, Case no. 43, pp. 85-86. Reported also by L. Ehrlich, op.cit., p. 467. Similarly, the same court in P. v. Ministry of Finance, Judgment of 13.11.1923, Z.W.N.T.A., I, no. 180; Moczulak v. Ministry of Finance, Judgment of 8.06.1924, Z.W.N.T.A., II, no. 269; Ryczak v. Ministry of Finance, Judgment of 20.12.1922, Z.W.N.T.A., I, no. 15.

20 Judgment of the Supreme Administrative Court, Z.W.N.T.A., I, 1923, no. 259. Cited by L. Ehrlich, op.cit., p. 467.

21 Dzierzbicki v. District Electric Association of Częstochowa, Judgment of the Supreme Court of 21.12.1933, O.S.P., 1934, no. 288; Annual Digest, 1933-1934, Case no. 38, p. 89. Cf. W. Czapliński, State Succession and State Responsibility, 'Canadian Yearbook of International Law' 1991, vol. 28, p. 349. 
internationally wrongful acts committed before the date of succession, and the obligation arising from the commission of such acts should not be transferred to the successor State. ${ }^{22}$

In Dzierzbicki, the Supreme Court dealt with a claim arising from an accident caused by the Russian railway authorities in a territory which was at that time still part of the Russian Empire. It held that:

In accordance with the views of the contemporary science of international law, the new State is not the legal successor of the previous State from which it took over part of the territory, and is responsible for the charges and debts only in so far as it has expressly assumed them. There is no reason for not applying this principle to the obligations of the partitioning Power arising from the responsibility for damage and losses caused in the course of running railways. ${ }^{23}$

The Court also observed that under the Peace Treaty of Riga of 1921, entered into by Russia and Poland, the new Polish State had not accepted responsibility for such obligations.

In Niemiec and Niemiec v. Bialobrodziec and the State Treasury, ${ }^{24}$ an incident took place in 1917 in a territory then part of Austria-Hungary where the plaintiffs' building was destroyed by a fire which had allegedly been caused by sparks from the engine of a passing train belonging to Austria's State railways. In Olpinski v. the Treasury (Railway Division), ${ }^{25}$ the case concerned the damage caused to Mr Olpinski in 1918 by the conductor of a train in a territory that was still under Austria-Hungary rule. Olpinski later sued the Polish Treasury, since the Polish State took over the Austrian State railways on its territory. The lower court adjudicating on the matter assumed that the new State cannot take assets without taking over liabilities. The Supreme Court rejected the claim and decided that the plaintiff should bring the case against the Austrian railway, since this

22 P. Dumberry, State Succession to International Responsibility, Martinus Nijhoff Publishers 2007, pp. 146-148.

${ }^{23}$ Dzierzbicki v. District Electric Association of Częstochowa, op.cit. A sum was awarded by a Russian Court in Warsaw in 1914.

24 Niemiec and Niemiec v. Bialobrodziec and Polish State Treasury, Judgment of the Supreme Court of 20.02.1923; 2 Annual Digest, Case no. 33, p. 64. Cf. D.P. O'Connell, Recent Problems of State Succession in Relation to New States, R.C.A.D.I. vol. 130, 1970-II, p. 163.; State Succession, vol. I, p. 493.

${ }^{25}$ Olpinski v. the Treasury (Railway Division), Judgment of the Supreme Court of 16.04.1921, O.S.P., I, no. 15; Annual Digest, 1919-1922, Case no. 36, p. 63. 
State continued to exist after 1918. In both decisions, the Supreme Court concluded that Austria was not a new State and that, accordingly, it should be held accountable for the illegal acts committed by Austria-Hungary.

An interesting issue of succession in respect to judgments was raised in Knoll v. Sobel. ${ }^{26}$ A dispute between the same parties had been decided by the Supreme Court of Austria in 1917. In 1924, the same action was brought to Polish court, where the defendant then resided and which, up to 1918, was Austrian. The District Court, on the objection of res judicata, refused to entertain the action. The Court of Appeal in Lviv reversed this decision. The Supreme Court upheld the decision of the Court of Appeal, arguing that the Austrian judgment, having originated in a court which had no jurisdiction over territory later ceded to Poland (the decision was first given by a district court in Vienna), was a foreign judgment which, for lack of reciprocity, was not enforceable.

To sum up this jurisprudence, it must be said that Polish courts viewed the succession in a case of secession as optional. The successor State does not take over any kind of rights or obligations of the predecessor, with the exception of those for which the successor agreed. This is in concordance with general State practice. The Polish judgments, which were criticised or even met with rejection by the PCIJ, concerned succession based on a treaty, e.g. the Treaty of Versailles, which was interpreted differently by both Poland and the PCIJ. ${ }^{27}$

\section{Consequences of the occupation of enemy territory}

The practice of Polish courts is also valuable when it comes to determining the effects of the occupation of enemy territory. Apart from the views of some Polish courts that the partition of Poland was in fact an occupation, the succession of Poland followed the military occupation of some of its territory during World War I.

In general, the judges thought that after the end of the occupation, the State had no obligation to maintain the regulations introduced by the

26 Knoll v. Sobel, judgment of the Supreme Court of 20.05.1925, O.S.P. IV, no. 547; Annual Digest 1925-1926, Case no. 72, pp. 94-95.

27 The decisions of Polish courts concerning Rentengüter as, inter alia cited in this article, State Treasury v. Von Bismarck were criticised by PCIJ, see contrary finding of this Court in Advisory Opinion of 10.09.1923 on German settlers (Series B, no. 6). 
occupant and may continue to apply the provisions in force before the occupation or adopt new ones. It did not matter whether the occupying Powers acted in accordance or not with The Hague Regulations.

In 1923, in Tajtel v. the Ministry of Agriculture, the Supreme Court refused to accept the act of German authorities observing that 'undoubtedly (...) the basis of the power of the invader is strength, not the law'. ${ }^{28}$ The case concerned the claim of the tsarist government secured by a mortgage belonging to Tajtel. During the war, a part of the debt was repaid by Tajtel to German occupation authorities, which, agreeing to the deduction of the alleged counter-claim, allowed the entire debt to be deleted from mortgage. Tajtel's request to delete the claim was rejected by the Supreme Court. The Supreme Court in Tajtel relied instead on the decree of the Chief of the State (Naczelnik Państwa) of 1919, which considered null and void contracts entered into by the occupying Powers except for contracts for normal income in the field of user rights.

In Graffowa and Wolanowski v. Ministry of Agriculture and State Lands, ${ }^{29}$ the plaintiffs were owners of an estate near Warsaw. In 1914, the German army, which occupied the territory in question, took from the estate a number of cattle. In 1916, the German authorities instituted compulsory administration of the estate and placed on it other cattle. After the withdrawal of the German authorities, the plaintiffs took over the administration of the estate. The Polish Ministry requested ownership of the cattle which had been placed there by the German authorities. The plaintiffs brought an action against the Ministry, claiming inter alia that it formed partial compensation for losses suffered by the owners through the German occupation. The Supreme Court dismissed the case on the ground that the new State became owner of all German State property on the territory of Poland (including the above-mentioned cattle), and Poland is not bound by the liabilities of the occupant. The Court referred here to Article 212 of the Treaty of Versailles for support on this view.

The other case concerned the legislative functions of the occupant. It is interesting that the act of the occupant was finally found effective. In 1924,

28 Tajtel v. Ministry of Agriculture and State Lands, Judgment of the Supreme Court of 28.04.1923, O.S.N. 1923, no. 53; Annual Digest Case no. 246, pp. 450-451. Cited by L. Ehrlich, op.cit., pp. 415-416.

29 Graffowa and Wolanowski v. Ministry of Agriculture and State Lands 3.03.1923, Annual Digest 1923-1924, Case no. 26, p. 55 et seq. O.S.N. 1923, no. 30; O.S.P. III, no. 230. Reported also by L. Ehrlich, op.cit., pp. 467-468. 
in Mariamoff and others v. Włocławek (Communal District of), ${ }^{30}$ the Supreme Court held that the decree of the German Governor-General introducing certain changes in the law concerning expropriation for reasons of public utility was valid. In particular, the decree authorised the Governor-General to order such expropriation where formerly it could only have been ordered by the Russian Emperor. The Court found that according to the principles well established in international law, while the occupant may not change the substantive law in force in the occupied territory, he may change the rules of procedure. The decree was in the nature of such a change.

The last case - Brust v. Polish Ministry of Communication ${ }^{31}$ - is particularly noteworthy, because it shows that the judges did not rely solely on the rigid principle of the absence of any continuity of obligations, but also sought to protect the interests of the applicants, in this case their right to a court. During the German occupation of the then Russian territory, which became Polish territory after 1918, the plaintiff lent to the office of a field railway in Krosniewice a lathe against receipt. The lathe was taken over by the Polish Ministry responsible for railways. The plaintiff sued the Ministry for return of the lathe or its value. The local court decided for the plaintiff, but the Court of Appeal held that the courts had no jurisdiction. The Supreme Court on appeal quashed this decision and sent the case for retrial. The Court observed that since the property was not confiscated nor requisitioned by the occupant by force, the plaintiff was not able to take steps against Germany under the Peace Treaty of Versailles (Article

30 In June 1918, the German Governor-General authorised the Communal District of Włocławek to carry out the expropriation of certain property belonging to the plaintiffs in order to extend the district hospital. The Commissioner of Włocławek issued an order against payment of a certain sum. The plaintiffs brought the case for higher compensation to the District Court of Włocławek, contending inter alia that the decree is invalid. They obtained a favourable judgment. However, the plaintiffs refused to accept the sum in question and demanded to be entered as owners in the land registry. Since the District Court had not shared their arguments, they appealed to the Supreme Court. Mariamoff and others v. Włocławek (Communal District of), Judgment of the Supreme Court of 5.12.1924, O.S.N. 1924, II, no. 167; O.S.P., V, no. 1.; Annual Digest 1923-1924, Case no. 243, pp. 444-445. Cited by L. Ehrlich, op. cit., p. 416. The thesis adopted by the Supreme Court was criticised. See Rundstein, in O.S.P., V, no. 1, in a note on pp. 1-5. Rundstein doubts whether the ruling of the Supreme Court is based on any established principle of international law, especially whether it is in accordance with The Hague Regulations. L. Ehrlich also thought that the occupying power may not adopt statutes (op. cit., p. 417).

31 Brust v. Polish Ministry of Communication, Judgment of the Supreme Court of 16.01.1925, O.S.N., I, 1925/I, no. I; Annual Digest 1925-1926, Case no. 52, pp. 73-74. 
232 and Annex I, Sub-section 9), and since Polish law had not excluded the jurisdiction of ordinary courts in such cases, the courts were bound to proceed.

The judgments cited here show that in settling disputes, domestic courts are not guided only by one sort of rules. Even rules derived from international law confirming the State's regulatory freedom after the end of the occupation can be balanced by reasons of public interest or individual rights.

\section{Nationality and statelessness}

The reborn State also had to deal with the issues of nationality. These issues came first in early cases concerning the responsibility for acts against the Polish State or responsibility for treason.

In Poland (Republic of) v. Karas, ${ }^{32}$ the defendant was taken as an Austrian prisoner by the Russian army in 1914 and later became an official of the new Soviet Government. He returned to Poland in 1921 and took up the office of a clerk in a court, which he had held before the war. He was prosecuted for his activities directed against the Polish State in Soviet service. He argued that at that time, he was an Austrian national and he did not know until his return to Poland that he had become a Polish citizen. His alleged crime was due to an error of fact and therefore not punishable. The Supreme Court held that in promoting hatred and contempt of the Constitution of Poland, the defendant had acted as a Polish citizen. Since the reestablishment of Poland, the defendant was a citizen of that State, being that he was a native of a village that formed part of Poland.

The other case refers to prosecution for treason. In Republic v. Siehen, ${ }^{33}$ the accused had been convicted by the district court in Vilna (Vilnius) as a Polish citizen, because during the war between the Republic of Poland and Soviet Russia, he collaborated with the enemy. Siehen appealed pleading that at the time of the alleged acts he was not a citizen of Poland. The Supreme Court quashed the conviction after establishing the criteria that must be satisfied to conclude that the territory was considered as forming

32 Poland (Republic of) v. Karas, Judgment of the Supreme Court of 14.08.1923, Annual Digest 1923-1924, Case no. 125, p. 239; Report: O.S.P., III, no. 205.

33 Republic of Poland v. Siehen, Judgment of the Supreme Court of 6.05.1926, O.S.P. VI, no. 28; Annual Digest 1925-1926, Case no. 10, pp. 16-17. 
part of Poland. The Court mentioned, among other things, that the territory must be in fact occupied by Polish armies, and there had been introduced in those territories a Polish administration, a Polish judiciary and a criminal code providing for the punishment of treason against Poland.

In Ettinger v. Ministry of Interior, ${ }^{34}$ the plaintiff contended that he was a Polish national by virtue of Article 4 of the Treaty between the Principal Allied and Associated Powers and Poland of 28.06.1919 signed in Versailles. ${ }^{35}$ The plaintiff domiciled in Vienna, and in 1927, he obtained an Austrian certificate to the effect that as from 16.06.1920 (the date of coming into force in Austria of the Treaty of St. Germain), he had lost his Austrian nationality, and he was to be considered a Polish national. According to Article 64 of this Treaty Austria declared to be Austrian nationals ipso facto and without the requirement of any formality all persons possessing at the date of coming into force of the Treaty rights of citizenship within Austrian territory who are not nationals of any other State. The Polish Ministry refused to recognise the certificate, assuming that Ettinger must be considered an Austrian citizen and that Austria could not decide on the Polish nationality because it was not a party to the Treaty of Versailles.

On appeal, the Supreme Court found that the claim of the plaintiff was well founded and the reasoning of the Ministry was wrong:

For it follows from the essence of sovereignty of a State that the question whether a certain person is the national of a State must be decided by that State. Thus, the decision whether the plaintiff is, by virtue of Article 64, an Austrian national, lies within Austrian authorities. An authority which is competent to make a decision is ipso facto competent, unless specific legal provisions stipulate the contrary, to take into consideration all facts which are material for the decision. Consequently, the administration of the city of Vienna was entitled to take into account, for the purposes of its certificate, the question whether the plaintiff is a 'Polish national'. ${ }^{36}$

34 Ettinger v. Ministry of Interior, Judgment of the Supreme Administrative Court of 22.01.1932, Annual Digest 1931-1933, Case no. 15, p. 37 et seq.

35 Under Article 4 of the Treaty of Versailles, Poland admitted and declared to be Polish nationals ipso facto and without the requirement of any formality persons of German, Austrian, Hungarian or Russian nationality who were born in the territory of Poland of parents habitually resident there, even if at the date of the coming into force of the Treaty they were not themselves habitually resident there.

36 Ibidem. 
Thus, the Austrian administration may rely on the effects of the Treaty of Versailles whether or not Austria is a party to it.

The Polish courts also developed rules concerning the treatment of stateless persons. Their position was not regulated by Polish law, but the Court found that they have to be treated equal to Polish citizens, at least in relation to the poor persons' procedure provided for by the Code of Civil Procedure. In the judgment of 11.12.1934, the Supreme Court ${ }^{37}$ supported this finding by general principles deduced from the Code of Civil Procedure, the Private International Law Act and Article 95 of the Polish Constitution, which guaranteed within the Polish territory the protection of life, liberty and property to all persons, without distinction of origin, nationality, language, race or religion. The Court explained that:

The general principles deducible from the above-mentioned provisions, when adapted to the needs of practice in the prevailing conditions of international relations, serve to fill this particular lacuna in the Code of Civil Procedure (...) and since Poland has consistently adopted a benevolent attitude towards efforts of the Nansen Office to secure to stateless persons the enjoyment of rights which foreigners normally enjoy on condition of reciprocity, there is no legal impediment to prevent stateless persons from being treated in the same manner as Polish nationals in so far as concerns poor persons' procedure. ${ }^{38}$

\section{Diplomatic and State immunity}

In addition to matters related to the reconstruction of Polish statehood, the courts dealt with other issues, e.g. questions of diplomatic immunity

37 A Russian refugee, holder of a Nansen passport, sought the benefit of the poor persons' procedure under the Polish Code of Civil Procedure. The provisions of the Code provided that aliens shall enjoy certain procedural advantages, including the benefit of the poor persons' procedure on condition of reciprocity. The lower courts refused the application, basing their decision on a literal reading of the Code, claiming that stateless persons are not citizens of any State, and reciprocity may not be established in their case. The Supreme Court based its decision on quite different reasoning. The situation of a stateless persons was not regulated in the Code. But the absence of the specific regulation does not imply that the legislature deliberately omitted to regulate their position, or that it is the same as that of aliens.

${ }^{38}$ Poor person's procedure case, Judgment of the Supreme Court of 11.12.1934, O.S.N., 1935, no. 239; Annual Digest 1935-1937 (ILR vol. 8), Case no. 141, pp. 311-312. 
or State immunity. This practice is also valuable, as it confirms certain important principles of international law which were later reflected in the 1961 Vienna Convention on Diplomatic Relations or the 2004 UN Convention on Jurisdictional Immunities of States and Their Property.

In Montwid-Biallozor v. Ivaldi, the Supreme Court held 'that municipal courts have jurisdiction in regard to the private immovable property of a public minister, except in regard to such immovable property as is devoted to the official use of the embassy or legation. ${ }^{39}$ This statement of the Court is quoted by the leading textbooks and commentaries on diplomatic law. ${ }^{40}$ The case concerned the action for eviction from a flat brought against an Italian military attaché as a result of the alleged expiry of the lease. The lease contract included a reservation that it would not be allowed to invoke a 'diplomatic clause'. Therefore, the Supreme Court had to deal with a waiver of diplomatic immunity. The Court explained in this regard that when it comes to questions whether a diplomatic representative or a member of a foreign mission can effectively renounce the privilege of immunity:

there is some discrepancy in academia(...) however (...), it is obvious that the court's immunity is not a personal privilege of one or another diplomat of a foreign state, but the privilege of the State itself, and so that a diplomat or other member of the diplomatic representation alone cannot dispose in this area; on the other hand, there may be exceptional circumstances in which both a diplomat and a foreign State consider submitting a dispute to national courts as desirable; then the foreign representative may accept national jurisdiction, but not otherwise, as under the express permission of his government; if it were not for a diplomatic representative but the other member of the mission, the diplomat's authorization as a representative of the foreign State would probably be considered sufficient; in any case, the defendant's respective declaration should be clear, firm and given in the case at hand before a court; occurred in a private contract, maybe even not contemporary, is an expression of the then intentions of the party towards the party, legally ineffective (...). ${ }^{41}$

39 Montwid-Biallozor v. Ivaldi, Judgment of the Supreme Court of 1925, O.S.N., C, I, 1925, no. 123, para. 140; OSP V, p. 366-370. L. Ehrlich, op.cit., p. 191. See also Annual Digest 1925-1926, pp. 324-325.

40 For instance, by E. Denza, Diplomatic Law, Commentary on the Vienna Convention on Diplomatic Relations, $3^{\text {rd }}$ ed., Oxford 2008, pp. 294-295; B.S. Murty, The International Law of Diplomacy: The Diplomatic Instrument and World Public Order, Martinus Nijhoff Publishers 1989, p. 354.

${ }^{41}$ Cited by L. Ehrlich, op. cit., p. 191. 
In 1925, the Supreme Court, in a case against the State Treasury of Czechoslovakia for damages caused by a car belonging to the State Treasury, was confronted with the issue of State immunity. The Court observed that:

the State Treasury of Czechoslovakia is denominating this State as a subject of property law (...) and Polish courts, generally, have no competence to adjudicate in cases against foreign State. Because States, as legal persons, are independent, they do not come under the authority of the other States and their reciprocal relations are governed by the treaties and the law of nations (...). It is not a question of 'extraterritoriality' (zakrajowość) but independence, 'sovereignty'. Therefore, if one State infringes the private rights of individual on the territory of the other State, not the territorial State authority but only international law could be applied to it. As a general rule, no State can exercise its judicial powers over the other State, except only for clear rule of the law of nation in that regard, voluntary acceptance of the jurisdiction and real estate cases. ${ }^{42}$

In Trade Delegation of U.S.S.R. at Warsaw v. Maurycy Fajans (Commercial and Industrial Stock $\left.C_{0 .}\right){ }^{43}$ the plaintiff applied for the execution of loan notes upon which the Company of Maurycy Fajans was liable. The District Court refused to put in force the execution clause on the ground that the application was made by an organ of a foreign State which could not be sued, without its express consent, before a Polish court and because, as a consequence, the debtor would be deprived of the right to court since he will not be able to file cross-appeals.

The Supreme Court found this reasoning incorrect. The Court explained that the District Court made a mistake qualifying the case as concerning diplomatic immunity while the subject of the right and party to the action was a State as a legal entity acting through its organ. The question of the locus standi in cases of a foreign State could be decided by a treaty, and being no such treaty, it had to be settled by applying 'the general principles of the so-called law of nations, based on customs which are accepted in the relations between States.' The Court further added that:

42 Judgment of the Supreme Court of 1925, O. S. P., V., 1925, no. 118, cited by L. Ehrlich, op.cit., pp. 99-100.

43 Trade Delegation of U.S.S.R. at Warsaw v. Maurycy Fajans (Commercial and Industrial Stock Co.), Judgment of the Supreme Court, O.S.N., C, I, 1928, no. 28; Annual Digest 1927-1928, Case no. 108, pp. 170-171. Cited also by L. Ehrlich, op.cit., p. 100 
according to universal opinion, a foreign State is entitled to enforce its civil rights, if it is recognised by the State in which it brings action, and of course if the claim is not contrary to the law of that State or to public order. The very fact of political recognition of a foreign State implies, subject to contrary reservation, the recognition of its personality at civil law. Hence results for the foreign State in question the right to concluding contracts with the citizens of the recognising State and of acquiring property (subject to certain reservations notably with regard to real estate). It is a further consequence of the same principle that the foreign State cannot be deprived of the possibility of enforcing its civil claims by actions at law, within limits of the local laws, and without excluding simplified proceedings such as, under our law, the endorsement of the executory clause. ${ }^{44}$

As the Soviet Union was concerned, by initiating the judicial proceedings against a local citizen, it

[h] ad by that very act recognised the jurisdiction of the Polish Court in this case and, having thus submitted to all the legal consequences of the proceedings which it had started, cannot plead its immunity, and in particular cannot use that plea to hinder or weaken the means of defence which are at the disposal of the debtor. ${ }^{45}$

These matters show that the Supreme Court perfectly understood the nuances of diplomatic law, the waiver of immunity and correctly distinguished the State's immunity from diplomatic immunities.

\section{Effects of treaties}

There was also a broad practice concerning various legal effects of treaties. Firstly, the courts had to define the role of treaties in the domestic legal order. For these purposes, they assumed that the treaty can be applied in national law only when it is enforced by that law. However, since the 1921 Constitution required the President of the State to obtain parliamentary consent prior to the ratification of certain categories of treaties, the courts accepted the legal fiction that these treaties turn into domestic laws, even more so because the consent of the Sejm took the form of the law.

44 Annual Digest 1927-1928, pp. 170-171.

45 Ibidem, p. 171. 
In Hardt in 1927, upon the argument that the bilateral treaty is contrary to an earlier multilateral treaty and cannot be applied, the Supreme Administrative Court (SAC) refused to review it. The Court observed that the treaty 'as ratified by an act of the President of the Republic of Poland (...) with reference to the authorization granted by law (...) and duly proclaimed in the Journal of Laws, (...) must be treated equally with the law duly promulgated, and SAC (...) has no right to review duly promulgated laws. ${ }^{46}$

The Supreme Court in 1928 observed that 'a treaty, when ratified and duly published (...) becomes a statutory instrument and gains a binding force in the domestic legal relations. ${ }^{47}$ The further consequence of the transformation of a treaty into the domestic statute was that a subsequent treaty prevailed only over legislative acts of an earlier date (lex posterior derogate legi priori). ${ }^{48}$ This dualistic approach was confirmed in several judgments of ordinary courts and continued until 1952 when the new constitution was adopted. ${ }^{49}$

In the discussed period, the courts responded to many questions related to the law of treaties in conformity with the rules codified later in the 1969 Vienna Convention of the Law of Treaties. We will give only two examples. The first one concerns the effects of the authentic texts of a treaty and reflects the rule enshrined in Article 33(1) of the Convention. ${ }^{50}$

46 Hardt, Judgment of the Supreme Administrative Court of 1927, W.N.T.A., V, 1927, no. 1345, cited by L. Ehrlich, op. cit., p. 237.

47 Judgment of the Supreme Court of 14.12.1928, 'Przegląd Prawa i Administracji' 1930, p. 476; similarly, Judgment of the Supreme Court of 23.10.1929, 'Przegląd Prawa i Administracji' 1930, p. 1.

48 See, to this effect, Judgment of the Supreme Administrative Court of 8.01.1930, O.S.P., vol. 10, p. 524.

49 See L. Garlicki, M. Masternak-Kubiak, K. Wójtowicz, Poland, [in:] D. Sloss, 'The Role of Domestic Courts in Treaty Enforcement, A Comparative Study', Cambridge University Press 2013, pp. 370-409. Cf. A. Wyrozumska, Poland, [in:] D.L. Shelton (ed), 'International Law and Domestic Legal Systems: Incorporation, Transformation, and Persuasion', Oxford University Press 2011, pp. 468-499; A. Wyrozumska, Umowy międzynarodowe. Teoria i praktyka [International agreements. Theory and practice], Prawo i Praktyka Gospodarcza 2006, p. 538; R. Kwiecień, Miejsce umów międzynarodowych w porzq̨dku prawnym państwa polskiego [Place of international agreements in the legal order of the Polish state], Wydawnictwo Sejmowe 2000, p. 101.

50 Article 33 (1) of the Vienna Convention reads: 'When a treaty has been authenticated in two or more languages, the text is equally authoritative in each language, unless the treaty provides or the parties agree that, in case of divergence, a particular text shall prevail.' 
In 1930, in the case of several archdukes from the House of HabsburgLorraine against the State Treasury concerning the property of the Cieszyn Chamber, the applicants argued inter alia that only the French text of the Treaty of St. Germain is absolutely binding, and only this text should be taken into account by the Court. The Supreme Court explained that, from the provision of the Treaty of St. Germain, the text of the treaty was agreed upon in French, English and Italian, and in the event of discrepancy, the French text should prevail (except for parts I and XIII):

follows the binding force of all three texts, as editorial, and therefore authentic, if there is no discrepancy between them. The discrepancy is therefore necessary to take the French and Italian texts from their essential equivalence. The will of the contracting parties has gone in such a direction that all texts, as an expression of their will, are taken into account in resolving a specific legal issue on the basis of the treaty and to examine whether these texts have the same content or content that is materially and logically different. In the latter case only the French text should be valid. ${ }^{51}$

The second case is particularly interesting for the courts' understanding of the operation of the principle of good faith. Polish courts recognised that it prohibits the performance, by one or some of the contracting parties in the period between signing and ratifying the treaty, of acts the purpose or necessary effect of which are to prevent or significantly impede the implementation of the provisions of the treaty or bring significant changes to the subject of the treaty. The rule is reflected nowadays in Article 18 of the 1969 Vienna Convention. ${ }^{52}$

In 1926, in Schrager $v$. the Institution for Insurance of Workers from accidents for Moravia and Silesia, the Appellate Court in Katowice held that the application of the provision of the Polish valorisation regulation of 1924 aimed at retorting against States that did not treat Polish citizens

51 Judgment of the Supreme Court of 1930, O.S.P., X. 153; the text commented in Annual Digest 1929-1930, Case no. 235; cited by G. Hackworth, Digest of International Law 1940-1944, vol. V, p. 267; Ch. Rousseau, Principes généraux du droit international public, Paris 1944, vol. I, pp. 720-721. Cited by L. Ehrlich, op. cit., pp. 247-248.

52 Article 18 of the Vienna Convention reads: 'A State is obliged to refrain from acts which would defeat the object and purpose of a treaty when: (a) It has signed the treaty or has exchanged instruments constituting the treaty subject to ratification, acceptance or approval, until it shall have made its intention clear not to become a party to the treaty; or (b) It has expressed its consent to be bound by the treaty, pending the entry into force of the treaty and provided that such entry into force is not unduly delayed.' 
as equal to their own requires taking into account the changes caused by the signing of the Polish-Czechoslovak agreement of 23.04.1925 and the announcement of the Act of 30.07.1925 authorising the Polish President to ratify this agreement.

The Appellate Court noted that:

the relevant agreement is currently being discussed at the Czechoslovak Seimas, it will be effective in the near future and this is also indicated by the fact that the ratification instruments have already been exchanged for a number of further agreements that have been negotiated between these countries. It should be admitted, however, that the agreement aimed at regulating mutual legal relations has not actually entered into force, because the instruments of ratification have not been exchanged, that in view of the presented state of affairs, it would be contrary to the principles of equity, if in this period the citizen of Czechoslovakia has been denied the right to use valorisation provisions and instead the retaliation provisions were applied. ${ }^{53}$

After the ratification, announcement and entry into force of this agreement in 1926, the Supreme Court in 1927 approved the decision of the lower court. ${ }^{54}$

The Supreme Court used the same reasoning in regard to the consequences of the signing of the Versailles Treaty, not recognising the rights to property acquired by German settlers after 28.06.1919. ${ }^{55}$ On the other hand, the PCIJ in the Advisory Opinion on German settlers in the areas surrendered to Poland by Germany recognised that the Treaty

53 Schrager v. the Institution for Insurance of Workers from accidents for Moravia and Silesia, Judgment of the Appellate Court in Katowice of 4.03.1926, cited by L. Ehrlich, op.cit., p. 228.

54 Judgment of the Supreme Court, 'Przegląd Prawa i Administracji' 1927, pp. 295-296, cited by L. Ehrlich, op.cit., p. 228.

55 See e.g. the Judgment of the Supreme Court in Polish State Treasury v. Von Bismarck, op.cit. The defendant was the heir of a person who in 1912 had concluded with the Prussian Treasury a contract for the acquisition of certain property. The contract was completed, and the defendant became the owner in September 1919. The Polish State Treasury claimed that after the signing of the Treaty of Versailles on 28.06.1919, the Prussian Treasury could not legally dispose of the property in the territory, which under Article 256 of the Treaty had been taken over by Poland. The Court concurred with the Polish State Treasury that the transfer of property to the defendant, having taken place after the signing of the Treaty of Versailles, 'is contrary to the stipulations and the spirit of the said Treaty'. 
of Versailles only obliged Germany to cede the territory to Poland in the future when the Treaty entered into force. The German States continued to be 'competent to undertake transactions falling within the normal administration of the country' during the period between the signing and entry into force of the Treaty. ${ }^{56}$ Similarly, the PCIJ rejected the argument based on good faith in regard to the transfer by Germany of the Chorzów factory to the private owners. ${ }^{57}$

Differences related to the interpretation of the treaties on which Polish statehood was based do not contradict the achievements of Polish courts in the understanding of the meaning of the principle of good faith in the law of treaties and its scope of application.

56 The PCIJ held that 'on June $28^{\text {th }}, 1919$, when the Treaty of Peace and the Minorities Treaty were signed, although Poland was recognised as exercising sovereignty over portions of the former Russian Empire, the cession and occupation of the German territories were left to be effected by the coming into force of the Treaty of Peace, and the German Government as well as the Prussian State is to be considered as having continued to be competent to undertake transactions falling within the normal administration of the country during that period. Earlier dated were applied in Alsace-Lorraine by virtue of special and specific provisions of the Treaty.' Advisory Opinion of the PCIJ on German Settlers in Poland of 10.09.1923 (Series B, no. 6), p. 28.

57 Poland had contended that the transaction by which the transfer was effected took place at a date when the Treaty of Versailles was signed though not yet in force. Since the Treaty of Versailles did not permit Germany to alienate property, the action of the German Government in selling property situated in the territory included in the cession (the cession was conditional upon the result of the plebiscite), and placing the value of this property outside this territory was contrary to international law, which is essentially based on the good faith of the contracting Parties. The PCIJ rejected this argument by observing that 'as, after its ratification, the Treaty did not, in the Court's opinion, impose on Germany such obligation to refrain from alienation, it is, a fortiori, impossible to regard as an infraction of the principle of good faith Germany's action in alienating the property before the coming into force of the Treaty which had already been signed'. Case concerning certain German interests in Polish Upper Silesia (The Merits), Series A, no. 7, p. 40. The Court underlined that: 'Germany undoubtedly retained until the actual transfer of sovereignty the right to dispose of her property, and only a misuse of this right could endow an act of alienation with the character of a breach of the Treaty; such misuse cannot be presumed, and it rests with the party who states that there has been such misuse to prove his statement.' (ibidem, p. 30). 


\section{Conclusion}

We could focus only on selected judgments of Polish courts; however, even from this simplified review, one can clearly see how many different cases based on international law reached Polish courts in the discussed period. These were issues of various types: recovering property seized and sold to other people by the partitioning State as a repression for participation in the national uprising, regaining the lathe taken over by the occupant, determining the moment of acquiring Polish citizenship, waiver of the immunity of a foreign State and immunity of a diplomatic representative, as well as the effectiveness and interpretation of treaties. The judges had no doubt that they should apply international customary law, general principles of law or international agreements, although there were no explicit legal provisions in Polish law at the time to authorise them to do so.

Some of their judgments could be criticised as being biased by national interests, while others seem convincing and shaping international law. These have been cited by various authors, since many of them were accessible to the broader international public, owing first of all to the reports in the Annual Digest.

\section{Bibliography}

1. Czapliński W., State Succession and State Responsibility, 'Canadian Yearbook of International Law' 1991, vol. 28

2. Denza E., Diplomatic Law, Commentary on the Vienna Convention on Diplomatic Relations, $3^{\text {rd }}$ ed., Oxford 2008

3. Dumberry P., State Succession to International Responsibility, Martinus Nijhoff Publishers 2007

4. $\quad$ Ehrlich L., Prawo Narodów, $3^{\text {rd }}$ ed., Kraków 1947

5. Garlicki L., Masternak-Kubiak M., Wójtowicz K., Poland, [in:] D. Sloss, 'The Role of Domestic Courts in Treaty Enforcement, A Comparative Study', Cambridge University Press 2013

6. Hackworth G., Digest of International Law 1940-1944, vol. V

7. Jennings R.Y., The Judiciary, International and National, and the Development of International Law, 'ICLQ', vol. 45, no. 1

8. Kwiecień R., Miejsce umów międzynarodowych w porządku prawnym państwa polskiego, Wydawnictwo Sejmowe 2000

9. Murty B.S., The International Law of Diplomacy: The Diplomatic Instrument and World Public Order, Martinus Nijhoff Publishers 1989 
10. O'Connell D.P., Recent Problems of State Succession in Relation to New States, R.C.A.D.I. vol. 130, 1970-II

11. O'Connell D.P., The Law of State Succession, Cambridge 1956

12. Rousseau Ch., Principes généraux du droit international public, Paris 1944, vol. I

13. Wyrozumska A., Poland, [in:] D.L. Shelton (ed.), 'International Law and Domestic Legal Systems: Incorporation, Transformation, and Persuasion', Oxford University Press 2011

14. Wyrozumska A., Umowy międzynarodowe. Teoria i praktyka, Prawo i Praktyka Gospodarcza 2006 